\title{
DETERMINANTS OF RETURN ON ASSETS IN ROMANIA: A PRINCIPAL COMPONENT ANALYSIS
}

\author{
Sorana VATAVU 1
}

DOI: 10.1515/tjeb-2015-0003

This paper examines the impact of capital structure, as well as its determinants on the financial performance of Romanian companies listed on the Bucharest Stock Exchange. The analysis is based on cross sectional regressions and factor analysis, and it refers to a ten-year period (2003-2012). Return on assets (ROA) is the performance proxy, while the capital structure indicator is debt ratio. Regression results indicate that Romanian companies register higher returns when they operate with limited borrowings. Among the capital structure determinants, tangibility and business risk have a negative impact on ROA, but the level of taxation has a positive effect, showing that companies manage their assets more efficiently during times of higher fiscal pressure. Performance is sustained by sales turnover, but not significantly influenced by high levels of liquidity. Periods of unstable economic conditions, reflected by high inflation rates and the current financial crisis, have a strong negative impact on corporate performance. Based on regression results, three factors were considered through the method of iterated principal component factors: the first one incorporates debt and size, as an indicator of consumption, the second one integrates the influence of tangibility and liquidity, marking the investment potential, and the third one is an indicator of assessed risk, integrating the volatility of earnings with the level of taxation. ROA is significantly influenced by these three factors, regardless the regression method used. The consumption factor has a negative impact on performance, while the investment and risk variables positively influence $R O A$.

Keywords: $\quad$ corporate performance, capital structure, factor analysis

JEL Classification: G32, C38.

${ }^{1}$ PhD Student, East-European Center for Research in Economics and Business (ECREB), West University of Timisoara, Romania 
Vatavu, S. (2015).

\section{Introduction}

Financing choices refer to corporate decisions resulting in an optimal capital structure. This represents a corporate financing mix, which maximises the value of the company and its market share price. Real economies are imperfect and unstable, offering investors limited access to external funds, due to information asymmetry and high transaction costs. While large financial markets ensure continuous trading activity by providing large liquidities for market participants, developing markets dispose of fewer securities, offering investors limited trading opportunities (Burhop \& Gelman, 2009). These constraints induce a preference for debt when it comes to accessing external finance for companies operating in developing countries, and thus these companies are expected to have relatively stable equity.

Many financing decisions theories were developed over time in order to demonstrate the purpose of capital mix and its role in company value. A few years after presenting the irrelevance theory, Modigliani and Miller (1963) revised the theory conditions, taking into account tax deductibility for interest expenses. Hence, the company value should be increased based on higher borrowings.

This paper intends to identify how debt ratio influences return on assets in companies listed on the Bucharest Stock Exchange (BSE), through a two-stage analysis, regression and factor analysis. Although the literature on capital structure and corporate performance is very broad, studies on Romania are limited in terms of the dimension of their samples. The sample analysed in this paper consists of 126 listed companies and it considers the findings of a previous empirical study, which indicated that fixed assets, liquidity, risk, taxation and inflation rate are determinants of financing decisions in Romanian companies (Vatavu, 2013). These factors are used as control variables, along with debt ratio, in order to identify the performance determinants. Although regression analysis is the common method of determining the relationship between capital structure and corporate performance, this study intends to test this relationship with a second method, factor analysis, by reducing the number of explanatory variables considered. This second analysis can also test the validity of results.

The remainder of this paper is structured as follows. After this brief introduction, the second section is an overview of empirical research regarding determinants of corporate performance. Section three describes the data collected, the empirical model and the hypotheses for variables used in model. Section four reports empirical results for both analysis methods and the last, section five, concludes.

DE GRUYTER OPEN
Timisoara Journal of Economics and Business | ISSN: 2286-0991 | www.tjeb.ro Year 2015 | Volume 8 | Issue 1s | Pages: 32-47 
Vatavu, S. (2015).

\section{Literature Review}

Funding companies through debt, rather than equity, avoid the dilution of corporate ownership. However, large capital sustained by shareholders' investment provides better credit profile. The risk is somehow shared: companies with higher equity tend to operate more conservatively if controlled by risk-averse shareholders, while companies with large borrowed funds reflect higher risks on their creditors. However, the leverage and equity ratios are not sufficient in determining performance, because there are multiple factors interfering in these relationships.

Akintoye (2009) demonstrated that the level of taxation, business risk, financial flexibility and managerial behaviour should be considered in the analysis of corporate performance. Based on the idea of a trade-off between risk and expected returns, he considered these crucial factors in determining an optimal capital mix. This optimum proportion can be followed considering that it minimises the cost of capital while maximising the company value. Moreover, any changes made in the level of debt or equity alters firms' value. According to fiscal benefits, it is expected that companies would borrow more in order avoid the tax burden and improve their performance.

The relationship between capital structure and performance is not clearly stated. There are studies demonstrating a positive relationship between total debt and performance, more specifically return on equity, while long-term debt carries a negative impact (Abor, 2005). A negative correlation between leverage and performance, described by return on assets, was found in Chinese firms (Huang \& Song, 2006; Chakraborty, 2010). There are also studies which could not find a significant relationship between financing choices and performance (Ebaid, 2009).

Whereas many capital structure determinants have an influence on profitability, the research on financing decisions and performance usually employs some of these determinants. Although Romanian companies use more debt in order to sustain their investments, they try to finance most of their fixed assets with internal funding. Moreover, in order to avoid risks, profitable companies and those registering high liquidities avoid leverage (Serghiescu \& Vaidean, 2013). In previous studies, it was demonstrated that Romanian manufacturing companies tend to follow the golden rule of financing: tangible assets are financed with longterm resources, while current assets are covered through short-term debt. The relationship between debt and the level of taxation indicates that tax savings are not the main reason for borrowing as these companies increase their liabilities when there is a lack of liquidity. Therefore, companies increase their business risk and access debt with short-term maturity when they are in financial distress. Moreover, companies access more debt with short maturity during times of high inflation rate (Vatavu, 2013).

DE GRUYTER OPEN
Timisoara Journal of Economics and Business | ISSN: 2286-0991 | www.tjeb.ro Year 2015 | Volume 8 | Issue 1s | Pages: 32-47 
Vatavu, S. (2015).

Determinants of Return on Assets in Romania: a Principal Component Analysis

Previous studies employed capital structure determinants in the analysis of performance in Romanian companies. Although a higher leverage is reducing earnings, some studies may indicate a positive relationship between debt and profitability, as long as profitable companies have efficient inventories (Burja, 2011). Boțoc (2011) and Pirtea, Nicolescu, \& Boțoc (2014) indicated a negative influence of debt on performance, proving that Romanian companies follow the pecking order theory, accessing debt only when they have insufficient internal resources. In addition, it was proven that firms with large amount of fixed assets are under performing, but fiscal pressure has a positive influence on profitability, although companies do not access borrowed funds in order to benefit from tax advantage.

\section{Data and Methodology}

\subsection{Sample data}

The sample data was gathered from the financial records of 126 companies listed on BSE, over a period of 10 years (2003-2012), and computed in Excel and Stata. In order to ensure results accuracy and objectivity, the companies were selected according to the following principles:

- delisted companies, those in dissolution stage, or those registering negative equity values were excluded in order to observe regular business activities; this reduces the number of outliers and the anomalous performance;

- only companies with all balance sheets available for every year were selected, in order to ensure data reliability.

\subsection{Methodology and descriptive statistics}

\section{A. Selection of indicators}

The capital structure indicators of the company include the financial indicators and nonfinancial indicators. Financial indicators have been widely adopted because the company's long-term goal is almost always purely financial in nature, and thus financial performance evaluation indicators are directly connected to corporate financial goals. The debt ratio is expected to have the greatest impact from all explanatory variables. In addition, tangibility, size, liquidity, risk, tax and the macroeconomic factors, inflation and crisis, will be used in order to explain the variance of performance. The formulas used for computing data are presented below:

$$
\begin{gathered}
R O A=\frac{\text { earnings before interest and tax }}{\text { total assets }} \\
\text { debt }=\frac{\text { total debt }}{\text { total assets }}
\end{gathered}
$$

\section{DE GRUYTER OPEN}

Timisoara Journal of Economics and Business | ISSN: 2286-0991 | www.tjeb.ro Year 2015 | Volume 8 | Issue 1s | Pages: 32-47 
Vatavu, S. (2015).

Determinants of Return on Assets in Romania: a Principal Component Analysis

$$
\begin{gathered}
\text { tang }=\frac{\text { fixed assets }}{\text { total assets }} \\
\text { size }=\log (\text { sales turnover) } \\
\text { liquid }=\frac{\text { current assets }}{\text { short-term debt }} \\
\text { tax }=\frac{\text { stdev }\left(\frac{\text { earnings before interest and tax }}{\text { total assets }}\right)}{\text { earnings before interest and tax }} \\
\text { inflcr }=\text { inflation rate } \times \text { crisis }{ }^{1}
\end{gathered}
$$

\section{B. Empirical model}

This study tries to discover some of the variables influencing corporate performance on a time series cross-sectional data over 2003-2012. ROA will be regressed on a group of variables; therefore, performance can be understood as follows:

performance $=f$ (debt, tangibility, size, liquidity, business risk, taxation, inflation, crisis)

The static linear models are presented in equation 10:

$R O A_{i t}=\alpha_{i}+\beta_{1}$ debt $_{i t}+\beta_{2}$ tang $_{i t}+\beta_{3}$ size $_{i t}+\beta_{4}$ liquid $_{i t}+\beta_{5}$ risk $_{i t}+\beta_{6}$ tax $_{i t}+\beta_{6}$ inflcr $_{i t}+\varepsilon_{i t}$

where $\alpha_{i}(\mathrm{i}=1 . . .126)$ is the unknown intercept for every company, $t(\mathrm{t}=2003 . . .2012)$ represents the year analysed, the $\beta$ s are the coefficients for every independent variable and $\varepsilon_{\text {it }}$ is the error term.

Several methods will be used to test the static models considered: Pooled Ordinary Least Squares (OLS), Fixed Effects with $n$ entity-specific intercepts (FE), Random Effects (RE) and a corrected model. The Hausman test will indicate which is more suitable for this analysis, the fixed or random effect model. Moreover, in order to correct the issues of heteroskedasticity and autocorrelation, a regression with necessary corrections will be estimated.

${ }^{1}$ Inflation rate-Eurostat website;

Crisis - dummy variable: 0 from 2003 to 2007; 1 from 2008 to 2012.

DE GRUYTER OPEN
Timisoara Journal of Economics and Business | ISSN: 2286-0991 | www.tjeb.ro Year 2015 | Volume 8 | Issue 1s | Pages: 32-47 
Vatavu, S. (2015).

Determinants of Return on Assets in Romania: a Principal Component Analysis

Fixed effects models explore the relationships between independent variables and the variable explained in separate entities, assuming that companies have their own characteristics that influence these correlations. On the contrary, random effects models imply a random variation across companies, uncorrelated to the explanatory variables. It is expected for the Hausman test to indicate that the fixed effect model is more appropriate for this sample analysis. Generally, capital structure and corporate performance accounts for differences across firms, thus requiring the use of firm fixed effects.

While Welch (2004) discovered that companies do not follow a target leverage, recent studies indicated an adjustment behaviour related to factors influencing debt ratios (Flannery \& Rangan, 2006; Lemmon, 2008; Huang \& Ritter, 2009). Static regression analysis does not overcome heterogeneity, an important issue which cannot be corrected in OLS or fixed and random effect models. Therefore, Generalized Method of Moments (GMM) will be used in the final step of the regression analysis. Comparing all results and their consistency, the most important relationships between capital structure, its determinants and performance will be discussed.

The dynamic panel model can be generally written as in equation 11, taking into consideration all independent variables (debt, tangibility, size, liquidity, business risk, taxation, inflation and crisis) in $\mathrm{X}$ :

$$
R O A_{i t}=\gamma R O A_{i t-1}+\beta X_{i t}+F_{i}+\varepsilon_{i t}
$$

From the models previously considered, OLS yields biased and inconsistent results, because OLS omits the fixed effect, $\mathrm{F}_{\mathrm{i}}$, and the fixed effect model, FE, estimates controls for the unobserved and time-invariant heterogeneity, but it also returns biased coefficient estimates. Specifically, the dynamic model can be written as follows:

$$
R O A_{i t}=\sum p_{j-1} \alpha_{j} R O A_{i, t-j}+x_{i t} \beta_{1}+w_{i t} \beta_{2}+v_{i}+\varepsilon_{i t}
$$

where $a_{j}$ are the estimated parameters, $x_{i t}$ is a $1 \times k_{1}$ vector of strictly exogenous covariates, $\beta_{1}$ is a $k_{1} \times 1$ vector of parameters to be estimated, $w_{i t}$ is a $1 \times k_{2}$ vector of predetermined or endogenous covariates, $\beta_{2}$ is a $k_{2} \times 1$ vector of parameters to be estimated, $n_{i}$ are the panellevel effects (which may be correlated with the covariates), and $\varepsilon_{i t}$ are independent and identically distributed over the whole sample with variance (Arrelano and Bover, 1995).

Blundell and Bond (1998) adjusted the previous dynamic model, proposing a system estimator that uses moment conditions. In addition to the moment conditions of lagged levels used as instruments for the differenced equation, lagged differences are also used as instruments, but in the level equation.

As long as ROA it is a function of the fixed effect, the lagged dependent variable should be correlated with the error term (Baltagi \& Liu, 2008). Accordingly, the within transformation removes the time-invariant unobserved heterogeneity as and introduces a correlation

DE GRUYTER OPEN
Timisoara Journal of Economics and Business | ISSN: 2286-0991 | www.tjeb.ro Year 2015 | Volume 8 | Issue 1s | Pages: 32-47 
Vatavu, S. (2015).

Determinants of Return on Assets in Romania: a Principal Component Analysis

between the transformed lag and the error. The dynamic model assumes an absence of second order serial correlation.

The final step of this analysis is the factor analysis is a multivariate statistical tool used for data reduction and summarisation. The method describes the variability among observed variables in terms of a lower number of unobserved variables, called factors. This means that the variation in a couple of observed variables can be explained by the variation in a single unobserved variable or that in a reduced number of variables. Through this statistical analysis a large number of variables can be combined into a single or reduced number of variables. In other words, factor analysis is used to evaluate the inter-relationships among a large number of variables, and explain these variables in terms of their common underlying factors with a minimum loss of information (Hair, Tatham, Anderson, \& Black, 2009).

\section{Descriptive statistics}

Based on the average return on total assets, most companies register limited earnings (approximately $4 \%$ of the total assets). The capital structure ratios prove a preference for equity, as the borrowed resources represent on average $34 \%$ of the capital in Romanian listed companies.

Tangibility indicates greater usage of fixed assets, but a relatively high standard deviation of this variable, meaning that the data points are spread out over a large range of values in terms of the proportion of fixed assets in total assets. The average size proxy (7.3) is rather large for most companies, comparing to the minimum (3) and maximum (10.3) values registered. Disregarding the extreme values, liquidity ratio shows that current assets exceed short-term debt over three times, the optimum value considered in theory. However, indicators show volatile earnings: although the average risk does not imply that Romanian companies face unstable earnings over long periods of time, the standard deviation of this variable is high. The tax ratio shows an average of approximately $25 \%$ and the variable composed of crisis and inflation rate has a maximum value of 0.079 , with an average of 0.029 .

Table 1. Descriptive statistics

\begin{tabular}{cccccc}
\hline Variable & Obs & Mean & Std. Dev. & Min & Max \\
\hline ROA & 1260 & 0.040 & 0.120 & -1.108 & 1.072 \\
debt & 1260 & 0.340 & 0.258 & 0.001 & 1.811 \\
tang & 1260 & 0.586 & 0.215 & 0.018 & 0.997 \\
size & 1260 & 7.302 & 0.823 & 2.966 & 10.290 \\
liquid & 1260 & 3.041 & 3.737 & 0.011 & 19.997 \\
risk & 1134 & 0.158 & 0.683 & 0 & 11.719 \\
tax & 1260 & 0.236 & 0.134 & 0 & 1 \\
inflcr & 1260 & 0.029 & 0.030 & 0 & 0.079 \\
\hline
\end{tabular}

DE GRUYTER OPEN 
Vatavu, S. (2015).

Determinants of Return on Assets in Romania: a Principal Component Analysis

\section{Correlations and related assumptions expected}

Based on Table 2, the higher the debt is, the less profitable the companies would be, as the return on assets should be sustained by equity. Besides debt, a large proportion of fixed assets and higher risks affect the performance of Romanian companies. These are more profitable when they register large liquidities and sales turnover, but also when tax rates increase. Finally, the inflation and crisis variable has a negative influence on ROA. Regarding debt ratio and its relationships with the rest of explanatory variables, these indicate opposite influences: size is the only variable with a direct impact on debt, while the other five variables (tangibility, liquidity, risk, taxation and inflation and crisis) have a constraining influence on borrowings.

Table 2. Correlations

\begin{tabular}{lllllllll}
\hline \multicolumn{1}{c}{ ROA } & debt & tang & size & liquid & risk & tax & inflcr \\
\hline ROA & 1 & & & & & & & \\
debt & -0.264 & 1 & & & & & & \\
tang & -0.171 & -0.332 & 1 & & & & & \\
size & 0.108 & 0.127 & -0.081 & 1 & & & & \\
liquid & 0.197 & -0.494 & -0.129 & -0.198 & 1 & & \\
risk & -0.009 & -0.059 & 0.033 & -0.125 & 0.213 & 1 & & \\
tax & 0.013 & -0.031 & -0.050 & 0.004 & 0.041 & -0.010 & 1 & \\
inflcr & -0.169 & -0.107 & 0.077 & -0.011 & 0.128 & 0.069 & -0.0084 & 1 \\
\hline
\end{tabular}

Based on the correlations, a set of assumptions can be considered. First of all, the relationship between capital structure, illustrated by debt ratio, and performance is negative. When profitability is high, a company earns more than what is needed to cover its obligations, therefore it does not have to raise external funding if it is producing and operating at high levels. Hence, the debt ratio should be influencing profitability indirectly. Second, investments in fixed assets are expected to return higher profits over medium or long term, and thus tangibility should have a negative impact on return on assets. Sales turnover should have a positive impact on performance, although a growth in sales is usually sustained by borrowed resources. The liquidities should have a direct impact on performance, while higher returns should be associated to companies facing fewer risks. Finally, corporate performance is expected to be directly influenced by taxation rates, but affected by the crisis and inflation rates.

\section{Results}

\subsection{Regression analysis}

The static regression models indicate that the return on assets is influenced by the debt ratio, tangibility, size and the inflation and crisis variable. In addition, liquidity is found statistically significant in the fixed effect model. Based on the Hausman test the fixed effect

DE GRUYTER OPEN
Timisoara Journal of Economics and Business | ISSN: 2286-0991 | www.tjeb.ro Year 2015 | Volume 8 | Issue 1s | Pages: 32-47 
Vatavu, S. (2015).

Determinants of Return on Assets in Romania: a Principal Component Analysis

model is preferred as it controls for differences between firms. Additionally, the estimated coefficients of the fixed-effects models take into account for omitted time-invariant characteristics. Previous researchers also concluded that fixed effects must be used to control for unobservable, time-invariant features of firms (Mackay \& Phillips, 2005; Lemmon, Roberts, \& Zender, 2008). All regression models are statistically significant. It is also important to mention that unit-root tests were applied to the panel data in order to inspect if there is a possibility for spurious correlations among variables. The tested hypothesis is that all panels contain unit-root and it was rejected showing that all the variables considered have a stationary trend, and hence the regression analysis can be performed.

The negative relationship between debt ratio and return on assets is statistically significant at $1 \%$ level, confirming the general assumption. When performance is stronger, companies register more earnings and meet their needs, and hence companies do not require external financing in order to continue their operating process. As long as the borrowed funds have a reduced proportion in capital structure and the profits are high, companies should have a stronger operational capacity. In addition, the higher the efficiency of managing assets, the more performing the company will be.

Tangible assets indicate a negative impact on return on assets, statistically significant at $1 \%$ level. This shows that Romanian companies with a high tangibility ratio register lower financial performance. On one side, large investments should have a positive impact on performance over a long period of time, considering the lack of financial resources after spending. Furthermore, the firms with higher fixed tangibility could have lower profit levels due to higher operating leverage. On the other side, this relationship could provide evidence that the sampled companies are not able to utilise their fixed assets efficiently, affecting their performance.

According to regression results, greater size values imply that companies have a good place on the market and development prospects. The positive influence on performance proxy should be linked in general to a strong solvency indicating that large firms operate more efficiently, benefiting from economies of scale, which can favourably impact the returns. Accordingly, larger firms may also be able to leverage their market power, thus having a positive effect on profitability (Onaolapo \& Kajola, 2010). This assumption is supported by the correlation between size and debt, indicating that Romanian companies with higher sales turnover operate with greater debt ratios.

Although the OLS model indicates a negative regression coefficient for liquidity, this is not proven statistically. On the contrary, the rest of the models return that liquidity has a negative impact on performance, with the specification that this is statistically significant only in the fixed effect models. As long as a higher degree of liquidity induces a decrease in return on assets, it can either be assumed that Romanian companies do not know how to invest their internal funds over short term, or that they dispose of cash flows because their operation process is limited.

DE GRUYTER OPEN
Timisoara Journal of Economics and Business | ISSN: 2286-0991 | www.tjeb.ro Year 2015 | Volume 8 | Issue 1s | Pages: 32-47 
Vatavu, S. (2015).

Determinants of Return on Assets in Romania: a Principal Component Analysis

Table 3. Comparative regression analysis

\begin{tabular}{|c|c|c|c|c|c|}
\hline & OLS & FE & RE & FE corrected & GMM \\
\hline lag & & & & & $\begin{array}{l}0.110 * * * \\
(0.016)\end{array}$ \\
\hline debt & $\begin{array}{l}-0.170 * * * \\
(0.015)\end{array}$ & $\begin{array}{l}-0.237 * * * \\
(0.022)\end{array}$ & $\begin{array}{l}-0.204 * * * \\
(0.018)\end{array}$ & $\begin{array}{l}-0.246 * * * \\
(0.044)\end{array}$ & $\begin{array}{l}-0.211 * * * \\
(0.055)\end{array}$ \\
\hline tang & $\begin{array}{l}-0.142 * * * \\
(0.016)\end{array}$ & $\begin{array}{l}-0.281 * * * \\
(0.026)\end{array}$ & $\begin{array}{l}-0.197 * * * \\
(0.019)\end{array}$ & $\begin{array}{l}-0.271 * * * \\
(0.052)\end{array}$ & $\begin{array}{l}-0.285 * * * \\
(0.040)\end{array}$ \\
\hline size & $\begin{array}{l}0.020 * * * \\
(0.003)\end{array}$ & $\begin{array}{l}0.025 * * \\
(0.011)\end{array}$ & $\begin{array}{l}0.018 * * * \\
(0.005)\end{array}$ & $\begin{array}{l}0.028 \\
(0.031)\end{array}$ & $\begin{array}{l}0.043 * * * \\
(0.006)\end{array}$ \\
\hline liquid & $\begin{array}{l}0.001 \\
(0.001)\end{array}$ & $\begin{array}{l}-0.004 * * * \\
(0.001)\end{array}$ & $\begin{array}{l}-0.002 \\
(0.001) \\
\end{array}$ & $\begin{array}{l}-0.003 * \\
(0.001)\end{array}$ & $\begin{array}{l}-0.002 \\
(0.001)\end{array}$ \\
\hline risk & $\begin{array}{l}0.000 \\
(0.004)\end{array}$ & $\begin{array}{l}-0.006 \\
(0.004)\end{array}$ & $\begin{array}{l}-0.004 \\
(0.004)\end{array}$ & $\begin{array}{l}-0.003 \\
(0.003)\end{array}$ & $\begin{array}{l}-0.003 * * \\
(0.001)\end{array}$ \\
\hline $\operatorname{tax}$ & $\begin{array}{l}-0.001 \\
(0.002)\end{array}$ & $\begin{array}{l}-0.001 \\
(0.002)\end{array}$ & $\begin{array}{l}-0.001 \\
(0.002)\end{array}$ & $\begin{array}{l}-0.001 \\
(0.001)\end{array}$ & $\begin{array}{l}0.005 * * * \\
(0.000)\end{array}$ \\
\hline infler & $\begin{array}{l}-0.719 * * * \\
(0.101)\end{array}$ & $\begin{array}{l}-0.614 * * * \\
(0.092)\end{array}$ & $\begin{array}{l}-0.675 * * * \\
(0.092)\end{array}$ & $\begin{array}{l}-0.525 * * * \\
(0.113)\end{array}$ & $\begin{array}{l}-0.308 * * * \\
(0.074)\end{array}$ \\
\hline cons & $\begin{array}{l}0.058 * \\
(0.032)\end{array}$ & $\begin{array}{l}0.135 \\
(0.084)\end{array}$ & $\begin{array}{l}0.115 * * * \\
(0.044)\end{array}$ & $\begin{array}{l}0.045 \\
(0.250)\end{array}$ & \\
\hline F-test & $39.71 * * *$ & $35.41 * * *$ & & $15.00 * * *$ & \\
\hline Wald $\left(\mathrm{chi}^{2}\right)$ & & & $260.11 * * *$ & & $466.70 * * *$ \\
\hline R-squared & 0.1980 & 0.1985 & 0.1914 & 0.1069 & \\
\hline Hausman $\left(\mathrm{chi}^{2}\right)$ & & & $52.42 * * *$ & & \\
\hline time FE (F test) & & $10.60 * * *$ & & & \\
\hline Modified Wald $\left(\mathrm{chi}^{2}\right)$ & & $110000 * * *$ & & & \\
\hline Wooldridge (F test) & & $8.040 * * *$ & & & \\
\hline $\begin{array}{l}\text { Sargan }\left(\mathrm{chi}^{2}\right) \\
\left(\text { Prob }>\mathrm{chi}^{2}\right)\end{array}$ & & & & & $\begin{array}{l}40.22 \\
(0.1808)\end{array}$ \\
\hline $\begin{array}{l}\text { Arellano-Bond test } \\
\text { order } 1 \mathrm{z} \text { (Prob>z) } \\
\text { order } 2 \mathrm{z}(\text { Prob }>\mathrm{z})\end{array}$ & & & & & $\begin{array}{l}-3.91 \\
(0.0001) \\
0.24(0.8101) \\
\end{array}$ \\
\hline
\end{tabular}

*, **, *** Significant at 10\%, 5\% and 1\% level, respectively

Standard errors are in parenthesis

The classic trade-off argument of risk returns considers that companies with higher volatility of operating income are expected to have higher returns. However, the results indicate that companies with higher risks have lower return on assets. These firms usually invest in more liquid assets if the return on these is relatively higher compared to that of long-term assets. In addition, firm that invest more in liquid assets will have a lower reliance on debt, resulting in a lower debt ratios. The correlations confirm this assumption, as long as they indicated a direct relationship between liquidity and risk, and a negative one between liquidity and debt. Furthermore, earning risks have a negative relationship with debt levels (Titman \& Wessels, 
Vatavu, S. (2015).

Determinants of Return on Assets in Romania: a Principal Component Analysis

1988) especially when the environmental conditions lead to higher earnings volatility. Currently, the risk management policies make companies more qualified to raise debt.

The use of debt produces tax savings, but due to interest payments and their financial constrains this involves greater risks. On the other hand, excessive rewards for shareholders increase the value of expected returns and therefore financing expenses increase. Whenever the capital structure accounts for a mix of sources of finance which minimizes the average costs of capital structure this leads to good performance is considered optimized one. According to static regressions, tax has a restraining impact on returns, but it is not statistically significant. However, the dynamic model indicates that companies are more efficient in terms of assets during times of high tax rates. This indicates that profitable firms pay a high tax rate. Considering previous relationships mentioned, there is no preference for debt when taxes are rising, which may indicate that Romanian companies do not raise borrowed resources in order to make tax savings.

The external factors, more specifically inflation and crisis, have a negative influence on return on assets. One of the main reasons for which inflation rate is targeted to be under control is to create an attractive environment for investment. In addition, during periods of crisis the operating processes and the sales are affected, reducing the earnings level. The regression results indicate a statistically significant relationship between performance and ,inflcr' variable: both higher inflation rates and current financial crisis affect the return on assets.

\subsection{Factor analysis}

The factor analysis describing the variability among observed variables (tangibility, size, liquidity, business risk, taxation, inflation and crisis) is presented in Table 4. Considering the eigen values greater than 1 , there is one principal factor composed from all independent variables considered. But based on the proportion of each factor, three of them cumulate almost all the impact.

Table 4. Factor analysis for determinants of return on assets

\begin{tabular}{lccccc}
\hline Variable & Factor & Eigen Value & Proportion & Cumulative & Loadings Factor \\
\hline lag & 1 & 1.394 & 0.554 & 0.554 & -0.809 \\
debt & 2 & 0.764 & 0.304 & 0.858 & 0.233 \\
tang & 3 & 0.280 & 0.111 & 0.969 & -0.241 \\
size & 4 & 0.044 & 0.017 & 0.986 & 0.764 \\
liquid & 5 & 0.035 & 0.014 & 1.000 & 0.208 \\
risk & 6 & -0.0002 & -0.0001 & 1.000 & 0.030 \\
inflcr & 1 & 1.394 & 0.554 & 0.554 & -0.809 \\
tax & 2 & 0.764 & 0.304 & 0.858 & 0.233 \\
\hline
\end{tabular}

DE GRUYTER OPEN 
Vatavu, S. (2015).

Determinants of Return on Assets in Romania: a Principal Component Analysis

According to the loadings and their positive or negative influence on factors returned, three factors will be predicted for further analysis. The first factor combines debt and size, and thus it can be considered a consumption indicator. The second one incorporates tangibility and liquidity, referring to investment opportunities. The third factor includes risk and taxation, reflecting financial difficulties and constraints that companies have to handle in their business process.

The three predicted factors and their coefficients are included in Table 5. The debt ratio and size variables have a positive impact on the consumption factor. While the proportion of fixed assets has a negative influence on the second factor, the liquidity ratio has a direct impact. Finally, the third factor has an indirect relationship with business risk and a direct relationship with taxes.

Table 5. Predicted factors based on comparative regression analysis

\begin{tabular}{ccc}
\hline Predicted factor & Component variables & Scoring coefficient \\
\hline \multirow{2}{*}{ consumption } & debt & 0.3064 \\
\multirow{2}{*}{ investment } & size & 0.3064 \\
& tang & -0.3045 \\
\hline \multirow{2}{*}{ constraints } & liquid & 0.3045 \\
& risk & -0.1005 \\
\hline
\end{tabular}

The performance proxy will be regressed on the three factors computed and the inflationcrisis variable. All results are included in table 6 in order to facilitate their comparison. Once again, the Hausman test indicated that fixed effects model is recommended for the analysed sample. The dynamic model showed that all variables are statistically significant, proving once again the role of independent variables in determining ROA.

The consumption variable has a negative impact on return on assets. This relationship is logic considering that past consumption shocks should predict high future excess returns. A large percent of borrowings will reduce the earnings level due to financial costs implied, and considering that borrowings are used to sustain the growing of Romanian companies, more specifically their sales, over a short-term an increase of consumption will inhibit the return on assets.

The second variable has a direct influence on returns, showing that companies with investment opportunities register higher returns. Considering that this factor consists of tangibility and liquidity, and based on the previous comments it is confirmed that fixed assets should restore higher returns over a period of time, while higher liquidity ratios can be associated with higher returns.

DE GRUYTER OPEN
Timisoara Journal of Economics and Business | ISSN: 2286-0991 | www.tjeb.ro Year 2015 | Volume 8 | Issue 1s | Pages: 32-47 
Vatavu, S. (2015).

Determinants of Return on Assets in Romania: a Principal Component Analysis

The financial constraints indicator shows a positive coefficient statistically significant in fixed and random effect models, and in GMM. Based on the initial variables and their influence on the constraints factor, it is confirmed that business risk has an inhibiting effect on return on assets, while a greater level of taxation usually ensures higher returns.

The influence of external factors, inflation and crisis, is confirmed once again, indicating a negative impact on the performance of Romanian companies.

Table 6. Regressions of factors on performance

\begin{tabular}{|c|c|c|c|c|c|}
\hline $\begin{array}{c}\text { Independent } \\
\text { Variable }\end{array}$ & OLS & FE & RE & FE corrected & GMM \\
\hline \multicolumn{6}{|l|}{ ROA } \\
\hline L1. & & & & & $\begin{array}{l}0.248 * * * \\
(0.027)\end{array}$ \\
\hline L2. & & & & & $\begin{array}{l}0.051 * * * \\
(0.019)\end{array}$ \\
\hline L3. & & & & & $\begin{array}{l}0.101 * * * \\
(0.022)\end{array}$ \\
\hline L4. & & & & & $\begin{array}{l}0.060 * * * \\
(0.015)\end{array}$ \\
\hline consumption & $\begin{array}{l}-0.021 * * * \\
(0.007)\end{array}$ & $\begin{array}{l}-0.069 * * * \\
(0.014)\end{array}$ & $\begin{array}{l}-0.036 * * * \\
(0.009)\end{array}$ & $\begin{array}{l}-0.069 * * \\
(0.027)\end{array}$ & $\begin{array}{l}-0.046 * * * \\
(0.012)\end{array}$ \\
\hline investment & $\begin{array}{l}0.060 * * * \\
(0.007)\end{array}$ & $\begin{array}{l}0.053 * * * \\
(0.010)\end{array}$ & $\begin{array}{l}0.057 * * * \\
(0.008)\end{array}$ & $\begin{array}{l}0.053 * * * \\
(0.018)\end{array}$ & $\begin{array}{l}0.095 * * * \\
(0.015)\end{array}$ \\
\hline constraints & $\begin{array}{l}0.019 \\
(0.022)\end{array}$ & $\begin{array}{l}0.049 * * \\
(0.022)\end{array}$ & $\begin{array}{l}0.040 * \\
(0.021)\end{array}$ & $\begin{array}{l}0.049 \\
(0.034)\end{array}$ & $\begin{array}{l}0.035 * * * \\
(0.008)\end{array}$ \\
\hline infler & $\begin{array}{l}-0.689 \\
(0.106)\end{array}$ & $\begin{array}{l}-0.734 * * * \\
(0.095)\end{array}$ & $\begin{array}{l}-0.070 * * * \\
(0.095)\end{array}$ & $\begin{array}{l}-0.734 * * * \\
(0.108) \\
\end{array}$ & $\begin{array}{l}-0.250 * * \\
(0.079)\end{array}$ \\
\hline cons & $\begin{array}{l}0.058 * * * \\
(0.004)\end{array}$ & $\begin{array}{l}0.059 * * * \\
(0.004)\end{array}$ & $\begin{array}{l}0.058 * * * \\
(0.006)\end{array}$ & $\begin{array}{l}0.059 * * * \\
(0.003)\end{array}$ & \\
\hline F-test & $31.05 * * *$ & $27.49 * * *$ & & $12.82 * * *$ & \\
\hline R-squared & 0.0991 & 0.0987 & 0.0945 & 0.0987 & \\
\hline Wald (chi²) & & & $117.92 * * *$ & & $270.92 * * *$ \\
\hline Hausman $\left(\mathrm{chi}^{2}\right)$ & & & $13.61 * * *$ & & \\
\hline $\begin{array}{l}\text { Sargan }\left(\mathrm{chi}^{2}\right) \\
\left(\text { Prob }>\mathrm{chi}^{2}\right)\end{array}$ & & & & & $\begin{array}{l}34.41 \\
(0.3529)\end{array}$ \\
\hline $\begin{array}{l}\text { Arellano-Bond test } \\
\text { order } 1 \mathrm{z}(\text { Prob }>\mathrm{z}) \\
\text { order } 2 \mathrm{z} \text { (Prob }>\mathrm{z})\end{array}$ & & & & & $\begin{array}{l}-3.39(0.0007) \\
-0.38(0.7044)\end{array}$ \\
\hline
\end{tabular}

$\star, \star *, * \star *$ Significant at 10\%,5\% and 1\% level, respectively

Standard errors are in parenthesis

In addition to these variables, the dynamic model results indicate that the performance proxy is heavily determined by its past levels. More specifically, return on assets can be increased gradually over the medium and long term, based on the four statistically significant lags. This also indicates that the explanatory variables - consumption,

DE GRUYTER OPEN
Timisoara Journal of Economics and Business | ISSN: 2286-0991 | www.tjeb.ro

Year 2015 | Volume 8 | Issue 1s | Pages: 32-47 
Vatavu, S. (2015).

Determinants of Return on Assets in Romania: a Principal Component Analysis

investment, constraints, inflation and crisis - have a significant influence on return on assets over a longer period of time. Compared to the previous GMM results (Table 3), these indicate that the influence of the aggregated variables on performance is not an immediate one, but one that occurs over the medium term. Considering the postestimation tests, this dynamic model is better than the previous one: the Sargan test has a probability of $35 \%$ (compared to $18 \%$ in Table 3). This means that we fail to reject the null hypothesis, and there are no valid overidentifying restrictions in the model. This regression analysis based on the predicted factors confirms the previous results, offering more insight in order to formulate better conclusions.

\section{Conclusions}

Considering the capital structure influence on performance, this study confirms most of the studies in developing countries, proving an indirect relationship between leverage and performance. Romanian listed companies follow the pecking order theory, operating on internal funding and in case this is insufficient, they require external financing in order to continue their activity. Due to a developing financial market, accessing resources through equity is uncommon for Romanian companies; hence the most accessible external financing is through borrowings.

Despite the fact that companies analysed follow pecking order theory, which somehow confers more financial stability, there are a couple of aspects which should be corrected in order to adjust corporate performance in Romania: companies show a deficiency in investing over short periods of time, as their internal funds are not used profitably, indicating more limited operating activities; although results indicated that large companies use their assets more efficiently, some correlations showed that sales growth is usually based on borrowing, which can increase the financial risk undertaken.

The proportion of tangible assets has a negative impact on return on assets, because investments in fixed assets produce a decrease in the profit levels. Moreover, as an outcome of undertaking profitable investments, higher profits are expected over a longer period of time, not immediately. Although it was not shown fixed assets are supported by debt, due to high inflation and interest rates, and economic instability, especially after 2007 when the crisis started, the Romanian companies were affected, indicating a decreasing return on assets.

Due to the absence of a well developed and a very liquid financial market, Romanian companies depend on credit institutions for external financing. The tax savings that the firm receives by using debt does not seem to be sufficient to outweigh the costs of using. With the cost of interest and the level of taxation being relatively high, even companies registering noticeable operating profits turn out to be poor financial performers in terms of the net profit levels. As long as the financial market ceases to develop, it would be practical for Romanian companies to reduce their borrowings and use internal cash flows and equity in order to meet their financing needs.

Although this research analyses a reasonable sample of 126 companies, over a ten year period, it is not homogenous in terms of company characteristics. Therefore, one of the limitations of

\section{DE GRUYTER OPEN}

Timisoara Journal of Economics and Business | ISSN: 2286-0991 | www.tjeb.ro Year 2015 | Volume 8 | Issue 1s | Pages: 32-47 
Vatavu, S. (2015).

Determinants of Return on Assets in Romania: a Principal Component Analysis

the study is disregarding the industry, or business activity. This study revealed the importance of macroeconomic factors (inflation rate and the current financial crisis) in the corporate performance: although Romanian companies try to protect against financial risk, following a pecking order theory, the unstable economic conditions could be overwhelming. Therefore, future research should also consider dividing the sample before and after the crisis, and analysing the sub-samples in order to observe if there is a change in the influence of performance determinants.

\section{Acknowledgement:}

This work was cofinanced from the European Social Fund through Sectoral Operational Programme Human Resources Development 2007 - 2013, project number POSDRU/159/1.5/S/134197, project title "Performance and Excellence in Doctoral and Postdoctoral Research in Romanian Economics Science Domain".

\section{References}

Abor, J. (2005). The effect of capital structure on profitability: an empirical analysis of listed firms in Ghana. Journal of Risk Finance, 6(5), 438-447.

Akintoye, I. R. (2009). Sensitivity of Performance to Capital Structure. Banking and Finance Letters, 1(1), 29-35.

Arellano, M., \& Bover, O. (1995). Another look at the instrumental variable estimation of error-components models. Journal of Econometrics, 68, 29-51.

Baltagi, B. H., \& Liu, L. (2008). Testing for random effects and spatial lag dependence in panel data models. Statistics \& Probability Letters, 78(18), 3304-3306.

Blundell, R., \& Bond. S. (1998). Initial conditions and moment restrictions in dynamic panel data models. Journal of Econometrics, 87, 115-143.

Boţoc, C. (2013). Profitability-capital structure trade off: case of publicly Romanian companies. The Annals of The University of Oradea, Economic Sciences, Tom XXII(1), 969-976.

Burhop, C., \& Gelman, S. (2009). Transactions Costs in an Emerging Stock Market: Berlin 1892-1913. Retrieved from www.ecore.be/Papers/1258364490.pdf

Burja, C. (2011). Factors influencing the companies' profitability. Annales Universitatis Apulensis, Series Oeconomica, 13(2), 215-224.

Chakraborty, I. (2010). Capital structure in an emerging stock market: The case of India. Research in International Business and Finance, 24(3), 295-314.

Ebaid, E. I. (2009). The impact of capital structure choice on firm performance: empirical evidence from Egypt. The Journal of Risk Finance, 10(5), 477-487.

Hair, J. F., Tatham, R. L., Anderson, R. E., \& Black, W. (2009). Multivariate data analysis (7th ed.). New Jersey: Prentice Hall.

Huang, S., \& Song, F. (2006). The determinants of capital structure: evidence from China. China Economic Review, 17(1), pp. 14-36.

Lemmon, M. L., Roberts, M. R., \& Zender, J. F. (2008). Back to the beginning: Persistence and the cross-section of corporate capital structure. Journal of Finance, 63, 1575-1608.

DE GRUYTER OPEN 
Vatavu, S. (2015).

Determinants of Return on Assets in Romania: a Principal Component Analysis

MacKay, P. G. (2005). How does industry affect firm financial structure? Review of Financial Studies, 18, 1432-1466.

Modigliani, F., \& Miller, M. (1963). Corporate income taxes and the cost of capital: a correction, American Economic Review, 53(3), 433-443.

Onaolapo, A. A., \& Kajola, S.O. (2010). Capital Structure and Firm Performance: Evidence from Nigeria. European Journal of Economics, Finance and Administrative Sciences, $25,70-82$.

Pirtea, M., Nicolescu C., \& Boţoc, C. (2014). Do Romanian companies follow pecking order financing? Journal of Economic Computation and Economic Cybernetics Studies and Research, 48(1), 49-64. Retrieved from http://www.ecocyb.ase.ro/nr20141/PIRTEA \%20Marilen.pdf

Serghiescu, L., \& Vaidean V. L. (2013). Determinant factors of the capital structure of a firm - an empirical analysis. Working paper EMQFB Tg Mures 2013.

Titman, S., \& Wessels, R. (1988). The determinants of capital structure choice. Journal of Finance, 43, 1-19.

Vatavu, S. (2013). Determinants of corporate debt ratios: Evidence from manufacturing companies listed on the Bucharest Stock Exchange. Timisoara Journal of Economics and Business, 6(20), 99-126.

Timisoara Journal of Economics and Business | ISSN: 2286-0991 | www.tjeb.ro

Year 2015 | Volume 8 | Issue 1s | Pages: 32-47 